\title{
Dispersion of U-series natural radionuclides in stream sediments from Edale, UK
}

\author{
Saifeldin M. Siddeeg*, Nicholas D. Bryan and Francis R. Livens
}

Centre for Radiochemistry Research, School of Chemistry, University of Manchester, Manchester, M13 9PL, UK.

\begin{abstract}
The spatial distribution of ${ }^{238} \mathrm{U}$-series radionuclides, specifically ${ }^{238} \mathrm{U},{ }^{234} \mathrm{U},{ }^{230} \mathrm{Th}$ and ${ }^{226} \mathrm{Ra}$, has been determined in stream sediments from Edale, Derbyshire, United Kingdom, to explore the behaviour of U-series radionuclides during weathering. For uranium and thorium, two different extraction methods were used, total dissolution with $\mathrm{HNO}_{3} / \mathrm{HF}$ in a microwave and leaching with aqua regia. This was followed by radiochemical separation using extraction chromatography, then alpha spectrometry measurement. The total radium contents in the sediments were measured using gamma spectrometry, while the leached fraction was measured in the same way as for uranium and thorium. The total sediment content of uranium and thorium ranges from $\sim 10$ up to $\sim 200 \mathrm{~Bq} \cdot \mathrm{kg}^{-1}$, while the radium specific activity lies between $\sim 15$ and $180 \mathrm{~Bq} \cdot \mathrm{kg}^{-1}$. In the aqua regia extractions, the uranium and thorium contents are in the range of $\sim 5$ to $\sim 100 \mathrm{~Bq} \cdot \mathrm{kg}^{-1}$, while the radium specific activities are similar to those measured by total dissolution. All the radionuclides show no correlation with organic matter content. The activity ratios ${ }^{234} \mathrm{U} /{ }^{238} \mathrm{U},{ }^{230} \mathrm{Th} /{ }^{238} \mathrm{U}$ and ${ }^{226} \mathrm{Ra} /{ }^{238} \mathrm{U}$ were used to determine the degree of radioactive disequilibrium. The data show disequilibrium in most of the sediments, with activity ratios of ${ }^{234} \mathrm{U} /{ }^{238} \mathrm{U},{ }^{230} \mathrm{Th} /{ }^{238} \mathrm{U}$ and ${ }^{226} \mathrm{Ra} /{ }^{238} \mathrm{U}>1$, inconsistent with evolution through straightforward weathering processes. Multivariate cluster analysis based on five variables, the specific activities of ${ }^{238} \mathrm{U},{ }^{234} \mathrm{U},{ }^{230} \mathrm{Th},{ }^{226} \mathrm{Ra}$ and loss on ignition,
\end{abstract}


was employed to group the data and identify five distinct clusters. There seems to be a link between high radionuclide concentrations and proximity to landslips.

\section{Introduction}

\subsection{Naturally occurring uranium:}

Uranium is a radioactive element with three naturally occurring isotopes $\left({ }^{234} \mathrm{U},{ }^{235} \mathrm{U}\right.$ and $\left.{ }^{238} \mathrm{U}\right)$. Among the three radioisotopes, ${ }^{238} \mathrm{U}\left(\mathrm{t}_{1 / 2}=4.468 \times 10^{9} \mathrm{y} ;>99.2\right.$ atom \%) is the parent of uranium series and ${ }^{235} \mathrm{U}$ is the parent of actinium series. Within the ${ }^{238} \mathrm{U}$, the daughter radionuclides with intermediate half-lives ${ }^{234} \mathrm{U}\left(\mathrm{t}_{1 / 2}=2.48 \times 10^{5} \mathrm{y}\right),{ }^{230} \mathrm{Th}\left(\mathrm{t}_{1 / 2}=7.52 \times 10^{4} \mathrm{y}\right)$ and ${ }^{226} \mathrm{Ra}\left(\mathrm{t}_{1 / 2}=1.6 \times 10^{3} \mathrm{y}\right)$ are crucial in studying U-series disequilibria ${ }^{1}$. As uranium both represents a significant component of radioactive wastes and may serve as an analogue for other actinides, its behaviour is interesting from a waste disposal point of view ${ }^{2}$

Uranium may exist in several oxidation states, with tetravalent and hexavalent being dominant in the environment. In oxic systems, such as river water and surface sediments, the higher oxidation state is favoured, whereas in anoxic environments the lower oxidation state is common ${ }^{3}$. In the hexavalent oxidation state, uranium is relatively more soluble and mobile depending on $\mathrm{pH}$ and redox conditions. This mobility may result either from complexation with different ligands (e.g. carbonates and hydroxides) or from binding to colloids in organicrich waters 4,5 .

Thorium in the environment, including radiogenic ${ }^{230} \mathrm{Th}$, predominantly exists in the tetravalent oxidation state. It has very low solubility and mobility in aqueous media at low temperature and $\mathrm{pH}>3^{4}$. However, in the presence of organic matter (e.g. humic and fulvic acids) thorium may be mobilised due to complexation ${ }^{6}$. It is expected that, in waters, the ${ }^{230} \mathrm{Th} /{ }^{234} \mathrm{U}$ ratio will be significantly lower than unity whereas, in sediment, produced by simple leaching of detrital rock fragments or minerals in rivers, it is expected the same ratio to be greater than unity ${ }^{7}$. 
Radium belongs to the alkaline earth metals and exhibits only the divalent oxidation state. Compared to uranium and thorium, it is highly reactive and can easily adsorb onto mineral surfaces and/or replace calcium in minerals. The radium distribution in weathering profiles in river waters is less well-documented than that of thorium and uranium. However, the cycling of radium by plants and its retention by organic matter in the soil profile may contribute to enrichment of Ra relative to Th and $\mathrm{U}^{5}$.

Erosion and chemical weathering modify rocks, and rivers enhance migration by carrying uranium away as part of the soluble phase, suspended matter or as sediments ${ }^{8}$. Rock mineralogy and water-solid interactions both lead to redistribution and transport of elements leached from rocks. In particular, colloids, organic matter and different mineral phases have a significant effect on uranium transport in the surficial environment ${ }^{9,10}$. Therefore, studying natural radionuclides in stream sediments provides insight into their sources, behaviour and fate along the river course.

\subsection{Fractionation of the ${ }^{238} \mathrm{U}$ series}

In a geological system, which has been closed for a sufficiently long time (ca $1.5 \mathrm{Ma}),{ }^{238} \mathrm{U}$ series isotopes will be in secular equilibrium so that the specific activity of the parent $\left({ }^{238} \mathrm{U}\right)$ and the intermediate-lived daughters $\left({ }^{234} \mathrm{U},{ }^{230} \mathrm{Th}\right.$ and $\left.{ }^{226} \mathrm{Ra}\right)$ are essentially equal. However, in the surface environment and because of the varied half-lives of the daughters, differences in the daughters' chemistry and presence of organic and inorganic colloids, radioactive disequilibrium is likely to be dominant $4,7,11$. Chemical weathering and water-rock interactions enhance this fractionation and, once it takes place, ${ }^{234} \mathrm{U} /{ }^{238} \mathrm{U}$ disequilibrium can last for 2 million years ${ }^{8,12}$.

In the case of the uranium isotopes $\left({ }^{238} \mathrm{U}\right.$ and $\left.{ }^{234} \mathrm{U}\right),{ }^{234} \mathrm{U}$ tends to exhibit a higher specific activity in the soluble phase ${ }^{7}$ due to: 
i) ejection of ${ }^{234} \mathrm{Th}$ from the grain to the surrounding liquid when its recoil range is greater than the distance to the grain boundary, followed by the decay of the short half-life ${ }^{234} \mathrm{Th}\left(\mathrm{t}_{1 / 2}\right.$ $=24$ days) to ${ }^{234} \mathrm{U}$;

ii) damage of the crystal lattice of the mineral grain from $\alpha$-decay events, which enhances the escape of the product nuclide from the damaged site ${ }^{7}$.

The result is an expected ${ }^{234} \mathrm{U} /{ }^{238} \mathrm{U}$ activity ratio greater than unity in waters and less than unity in river sediments ${ }^{13,14}$.

Additional fractionation, associated with chemical properties of the radionuclide in natural water, is expected in the U-series. The fractionation between Ra-Th-U occurs since thorium has very low solubility and tends to become associated with the solid phase, while uranium is more soluble in most surface environments and radium relatively displays intermediate solubility ${ }^{5}$. Thus, for example, the ${ }^{230}$ Th specific activity in sediments will depend both on the chemistry of its direct precursor $\left({ }^{234} \mathrm{U}\right)$ and interaction with the surrounding environment 15. The presence of colloids, particularly organic, also influences U-series fractionation through complexation of $\mathrm{Ra}$, Th and $\mathrm{U}$ that affects their mobility and modifies their distribution ${ }^{11}$.

\subsection{Objectives of the study}

This study investigates the spatial distribution of ${ }^{238} \mathrm{U}$-series radionuclides in sediments from Edale, focusing on ${ }^{238} \mathrm{U},{ }^{234} \mathrm{U},{ }^{230} \mathrm{Th}$ and ${ }^{226} \mathrm{Ra}$, to understand the behaviour and mobility of U-series radionuclides during weathering by identifying parameters controlling this mobility. This work aims to explore the phases of the minerals and/or organic matter involved in the retention of the U-series radionuclides and the level of association between these variables. 


\subsection{Materials and Methods}

\subsubsection{The study area}

Edale is located in Derbyshire, England in the valley of the river Noe. The river is fed by small streams flowing from the north and south. The Derbyshire Dome comprises an anticlinal structure of Carboniferous rocks, with limestone in the middle, and the Edale Shales on top in the west ${ }^{16}$. The bed rocks of the area are of Namurian age (326-313 million years), and are overlain successively by the Kinder Scout Grit, Bowland Shale Formation, Shale Grit, Mam Tor Sandstone and Edale Shales. The Kinder Scout Grit, which underlies the Kinder Plateau, is a coarse, massive rock. The Bowland Shales consists of dark grey mudstone and fine grained shale. The Shale Grit and Mam Tor Sandstone are sandstones with shale bands in the upper parts, and more frequent shales in the lower portion. The fine grained, dark shales, mudstones and thin siltstones that lie on top constitute the Edale Shales 17.

The Mam Tor hill, with its formation of Carboniferous sandstones and shales, is located at the south of the valley. The Mam Tor Beds, which contain shales, siltstones and fine-grained sandstones, are more dispersed on the southern side of the valley compared to the north. There are also many landslides, which have occurred over some thousands of years, on the southern side of the valley ${ }^{17}$.

During the Quaternary (2.56 million years to present), the softer formations in the sequence have been eroded and sediments derived from weathering of the shales were deposited along the valley. In particular, the Edale shales are relatively rich in uranium, with concentrations $\sim 50 \mathrm{ppm}$ reported ${ }^{18}$, and localised higher concentrations associated with phosphatic nodules at their base ${ }^{19}$.

\subsubsection{Sampling and sample pretreatment}

A total of 25 samples of stream sediment were collected from the Vale of Edale (Fig. 1), during two field trips (10 and 17 December 2010). The samples were collected by hands from 
the stream bank on a depth approximately at $5-10 \mathrm{~cm}$ beneath the surface water. They were saved in Kraft envelopes for further analysis in the laboratory. The samples were wet sieved through a $2 \mathrm{~mm}$ sieve, before being left to air dry in the laboratory. Once dry, they were disaggregated using a mortar and pestle and homogenised before chemical treatment. Approximately 1- $2 \mathrm{~g}$ of each sample, accurately weighed, was heated to $550{ }^{\circ} \mathrm{C}$ for 5 hours and loss on ignition measured in three replicates.

\subsubsection{Mineralogy of the samples}

The mineralogy of the sediments was examined qualitatively by XRD using an X'Pert Powder $\left(\mathrm{Cu} \mathrm{K} \mathrm{K}_{\alpha} 0.152 \mathrm{~nm}, 40 \mathrm{kV}, 30 \mathrm{~mA}\right)$ diffractometer equipped with a Multi-Channel Detector (X'Celerator). The samples were sieved ( $80 \mathrm{mesh})$ and appropriate amounts $(\sim 0.5 \mathrm{~g})$ were placed onto the sample holder. A smooth flat surface was obtained before introducing the specimen to the instrument. The exposure time was 30 minutes, and the phase identification for the collected spectrum was performed using the X'Pert HighScore Plus powder pattern analysis tool.

\subsubsection{Radiochemical characterisation}

\subsubsection{Sediment dissolution}

For total dissolution of the sediments, $0.2 \mathrm{~g}$ of the sediment was ashed in a muffle furnace at $550^{\circ} \mathrm{C}$ for 5 hours, and placed in a closed vessel and wetted overnight with a mixture of 1.0 $\mathrm{mL}$ deionised water, $3.0 \mathrm{~mL}$ concentrated nitric acid and $6.0 \mathrm{~mL}$ concentrated hydrofluoric acid. The sample was then digested in a microwave oven with ramping time 10 minutes to $140{ }^{\circ} \mathrm{C}(\sim 150 \mathrm{psi})$ and 50 minutes holding time, and this was repeated three times, before evaporation. Finally, $2.0 \mathrm{~mL}$ of $20 \%$ nitric acid was added to the residue and the volume was made up to $20 \mathrm{~mL}$ with deionised water. 
For leaching, a known amount of the sediment (from $0.5-2.0 \mathrm{~g}$ ) was ashed and then leached with $15.0 \mathrm{~mL}$ aqua regia (concentrated hydrochloric and nitric acids in a 3:1 ratio) at near boiling point for 3 hours. The aim was to extract the radionuclides which were not associated with primary minerals. In particular, the leached fractions include those associated with organic matter and secondary phases, adsorbed onto the surfaces of minerals ${ }^{2,20}$. After leaching, the extract solution was evaporated to about $2.0 \mathrm{~mL}$ and the volume was made up to $50 \mathrm{~mL}$ using $0.1 \mathrm{M} \mathrm{HNO}_{3}$.

\subsubsection{Uranium and thorium separation}

The experimental setup was based on extraction chromatography and modified from that proposed to separate $\mathrm{Th} / \mathrm{U}$ in geological samples ${ }^{21}$. To the ashed sediment, spikes of ${ }^{232} \mathrm{U}$ and ${ }^{229} \mathrm{Th}(40 \mathrm{mBq}$ and $50 \mathrm{mBq}$ respectively), prepared from certified standard solutions (CERCA LEA, France and National Physical Laboratory, U.K.) were added. To the sample solution, whether produced by total dissolution or leaching, 1 x $5 \mathrm{~mL}$ portion of concentrated $\mathrm{HNO}_{3}$ was added and the solution taken to near dryness under a heat lamp. The nitric acid treatment was repeated. The residue was dissolved in $10 \mathrm{~mL}$ of $3 \mathrm{M} \mathrm{HNO}_{3} / 1 \mathrm{M} \mathrm{Al}\left(\mathrm{NO}_{3}\right)_{3}$ and the solution centrifuged at $3000 \mathrm{rpm}$ for 10 minutes.

For thorium and uranium separation, Eichrom TEVA and UTEVA columns $(2 \mathrm{~mL}$ prepacked columns, Triskem, France) were utilised. Firstly, a TEVA column was preconditioned with $5 \mathrm{~mL}$ of $3 \mathrm{M} \mathrm{HNO}_{3}$ before the solution was loaded. The beaker was rinsed with $5 \mathrm{~mL}$ of $3 \mathrm{M} \mathrm{HNO}_{3}$ and transferred onto the column. The thorium fraction was retained on the column while the uranium fraction passed through. A further $30 \mathrm{~mL}$ of $3 \mathrm{M} \mathrm{HNO}_{3}$ was passed through the column and the eluent was saved for uranium purification. The thorium fraction was eluted with $20 \mathrm{~mL} 9 \mathrm{M} \mathrm{HCl}$ followed by $5 \mathrm{~mL}$ of $6 \mathrm{M} \mathrm{HCl}$, and the eluate was taken to dryness under a heat lamp. 
To purify the uranium, a UTEVA column was preconditioned with $3 \mathrm{M} \mathrm{HNO}_{3}$ before the uranium solution was loaded. After passage of the sample, the column was converted to the chloride form by adding $5 \mathrm{~mL}$ of $9 \mathrm{M} \mathrm{HCl}$ and $20 \mathrm{~mL}$ of $5 \mathrm{M} \mathrm{HCl}$ in $0.05 \mathrm{M} \mathrm{H}_{2} \mathrm{C}_{2} \mathrm{O}_{4}$. Finally, uranium was stripped with $15 \mathrm{ml}$ of $1 \mathrm{M} \mathrm{HCl}$ and the solution taken to dryness with a heat lamp.

For electrodeposition, $2.5 \mathrm{ml}$ of $5 \mathrm{wt} \% \mathrm{NaHSO}_{4}, 2 \mathrm{~mL}$ of deionised water and $5 \mathrm{~mL}$ of 15 wt. $\% \mathrm{NaHSO}_{4}$ was added to the residue of purified uranium and thorium fraction and heated. The solution was transferred to an electrodeposition cell and rinsed with $3 \mathrm{ml}$ deionised water, and $1 \mathrm{ml}$ of $20 \mathrm{~g} / \mathrm{L}\left(\mathrm{NH}_{4}\right)_{2} \mathrm{C}_{2} \mathrm{O}_{4}$ plating solution was added. The current was adjusted to $0.5 \mathrm{~A}$ for 5 minutes and then to $0.75 \mathrm{~A}$ for 90 minutes. 1 minute before the end, $2 \mathrm{ml}$ of 25 wt. \% potassium hydroxide was added and the power was turned off. The solution was discarded and the cell was washed with $2 \mathrm{ml} 5$ wt. $\% \mathrm{NH}_{4} \mathrm{OH}$. Finally, the stainless-steel counting source was rinsed consecutively with small volumes of ethanol and acetone.

\subsubsection{Total radium}

15-30 g amounts of dry sediments were sealed using insulating tape into double polypropylene containers and put aside for at least four weeks, to avoid the escape of ${ }^{222} \mathrm{Rn}$ and allow establishment of secular equilibrium between radium, radon and the short-lived daughters, ${ }^{214} \mathrm{Bi}$ and ${ }^{214} \mathrm{~Pb}$. The total specific activities of the radium in the sediments were measured by gamma spectrometry with a high purity germanium (HPGe) detector and $45 \%$ relative efficiency at $1.33 \mathrm{MeV}$. Before measurement of the samples, two standards were prepared by dispersing a known amount of ${ }^{226}$ Ra homogeneously through two samples, one with low organic content and one with high organic content, which both had low radium contents. This allows compensation for the effects of density and chemical composition. The samples were prepared in the same physical geometries (height, volume and density) as the standard, since the sample and the standard should have the same geometry, in order to make 
the calculation simple. The method was checked using a standard reference material, stream sediment 314, supplied by the International Atomic Energy Agency (IAEA).

The samples were counted for 12 hours, and the specific activity of ${ }^{226}$ Ra was estimated from measurements of the ${ }^{214} \mathrm{Bi}$ gamma line at $609 \mathrm{keV}$ and the ${ }^{214} \mathrm{~Pb}$ gamma line at $352 \mathrm{keV}$.

\subsubsection{Radium separation}

Radiochemical separation of radium was based on the method proposed by Smith and Mercer (1970) using ${ }^{225} \mathrm{Ra}(150 \mathrm{mBq})$ as a radiotracer. After leaching the ashed sediment as described for $\mathrm{U} / \mathrm{Th}$, the volume was made up to $50 \mathrm{ml}$ using $0.1 \mathrm{M} \mathrm{HNO}_{3}$. Radium was coprecipitated with $\mathrm{PbSO}_{4}$ after adding $1 \mathrm{~mL}$ of concentrated $\mathrm{H}_{2} \mathrm{SO}_{4}, 2 \mathrm{~g} \mathrm{~K}_{2} \mathrm{SO}_{4}$ and $1 \mathrm{ml}$ of $0.24 \mathrm{M}$ of $\mathrm{Pb}\left(\mathrm{NO}_{3}\right)_{2}$, consecutively. The solid was centrifuged in a $50 \mathrm{~mL}$ tube at $3000 \mathrm{rpm}$ for 10 minutes, and then washed with $20 \mathrm{~mL}$ of a mixture of $0.2 \mathrm{M} \mathrm{H}_{2} \mathrm{SO}_{4} / 0.1 \mathrm{M} \mathrm{K}_{2} \mathrm{SO}_{4}$.

The precipitate was dissolved in $5 \mathrm{~mL}$ of $0.1 \mathrm{M}$ ethylenediaminetetraacetic acid (EDTA)/ $\mathrm{NH}_{4} \mathrm{OH}(\mathrm{pH}$ 10), passed through an anion exchange column (Bio-Rad AG1-X8, 100-200 mesh, chloride form, $5 \times 0.5 \mathrm{~cm}$ ) to remove sulphate and washed with $13 \mathrm{~mL} 0.01$ EDTA/ $\mathrm{NH}_{4} \mathrm{OH}$. To the eluate, $1 \mathrm{ml} 5 \mathrm{M} \mathrm{CH}_{3} \mathrm{COONH}_{4}$ was added (pH 4.5) and the solution was passed through a cation exchange column (Bio-Rad AG50W-X12, 200- 400 mesh, 8 x $0.7 \mathrm{~cm}$ ) at a flow rate of $1 \mathrm{~mL} /$ minute. The column was previously conditioned with $15 \mathrm{~mL}$ $1.5 \mathrm{M} \mathrm{CH}_{3} \mathrm{COONH}_{4}$ followed by $15 \mathrm{~mL}^{0.25} \mathrm{M}_{\mathrm{CH}_{3} \mathrm{COONH}_{4} .} 50 \mathrm{~mL} \quad 1.5 \mathrm{M}$ $\mathrm{CH}_{3} \mathrm{COONH}_{4} / 0.1 \mathrm{M} \mathrm{HNO}_{3}$ was passed through this column to remove $\mathrm{Pb}$ and $\mathrm{Ac}$, while $\mathrm{Ba}$ was eluted by washing the column with $40 \mathrm{~mL} 2.5 \mathrm{M} \mathrm{HCl}$. Finally, Ra was eluted with 25 $\mathrm{mL} 6 \mathrm{M} \mathrm{HNO}_{3}$, and this solution was evaporated to dryness with care. The radium was redissolved in an organic electrolyte solution $\left(9 \mathrm{~mL}\right.$ ethanol in $1 \mathrm{~mL} 0.1 \mathrm{M} \mathrm{HNO}_{3}$ and $2 \mathrm{~mL}$ $0.05 \mathrm{HCl})$ and electroplated on to a stainless steel planchette at $120 \mathrm{~mA}$ for 30 minutes. 
The prepared alpha sources were measured by alpha spectrometry (Canberra Model 7401) equipped with passivated implanted planar silicon (PIPS) detectors (Canberra, Belgium, model A450) with $450 \mathrm{~mm}^{2}$ active area and alpha resolution (FWHM) $20 \mathrm{keV}$ at the 5.486 $\mathrm{MeV}$ alpha line. The planchettes were placed at $\sim 5 \mathrm{~mm}$ distance from the detector and a vacuum was applied. In these conditions, an absolute counting efficiency of $\sim 25 \%$ can be achieved. The acquisition time ranged from 1 to 10 days, depending on the activity of the sample. Pulses were collected and spectral analyses were performed using Genie 20003.1 software. Errors for individual measurements were estimated from counting statistics and ranged from 3.3 to $15.8 \%$.

\subsubsection{Quality control}

The analysis conducted, either for the total or the leached fraction, of the radionuclides was tested by regular quality control methods. For the radiochemical separation, the whole method was validated using blank samples spiked with the tracer, standard additions and standard reference material (IAEA-314). The blank analyses always gave less than 5 counts in each uranium region of interest, whereas all the sample analyses are based on signals of at least 100 counts. In the standard additions, where a known amount of ${ }^{238} \mathrm{U}$ was added to three duplicate samples and then the separation was performed on the two samples, the measured uranium recoveries were $89 \pm 13 \%, 116 \pm 12 \%$ and $87 \pm 15 \%$ of the added uranium. Aqua regia was used to leach the radionuclides associated with organic matter and secondary minerals. The results for the reference material were close to the recommended values (Table 1). 


\subsection{Results and discussion}

\subsubsection{Characterisation of the stream sediments}

Table 2 presents the mineralogical composition of the sediments from powder X-ray diffraction measurements. It is obvious that the dominant mineral phase in all samples is quartz, a primary mineral, with other minerals (albite, muscovite and kaolinite) also present in the sediments. Sediments in streams coming from the north side of the valley toward the River Noe comprise almost entirely quartz, while the majority of those running from the south side of the valley toward the River Noe have accessory minerals in addition to quartz. Loss on ignition of the sediments ranged from 2.0 to $18.0 \%$, with locations dominated by quartz having low organic matter, while those with clays are also rich in organic matter.

\subsection{2 ${ }^{238} \mathrm{U},{ }^{234} \mathrm{U},{ }^{230} \mathrm{Th}$ and ${ }^{226} \mathrm{Ra}$ contents of the sediments}

The specific activity of the total and the leached ${ }^{238} \mathrm{U},{ }^{234} \mathrm{U},{ }^{230} \mathrm{Th}$ and ${ }^{226} \mathrm{Ra}$, as well as ${ }^{234} \mathrm{U} /{ }^{238} \mathrm{U}$ and ${ }^{230} \mathrm{Th} /{ }^{238} \mathrm{U}$ activity ratios in Edale sediments are summarised in Tables 3 and 4. The total ${ }^{238} \mathrm{U}$ specific activities range from 9.0 to $184.0 \mathrm{~Bq} \mathrm{~kg}^{-1}$ and the leached from 5.0 to 91.0 $\mathrm{Bq} \mathrm{kg}^{-1}$. The total ${ }^{234} \mathrm{U}$ specific activities are in the range from 12.0 to $171.0 \mathrm{~Bq} \mathrm{~kg}^{-1}$, and the leached from 5.0- $90.0 \mathrm{~Bq} \mathrm{~kg}^{-1}$. The total specific activities of the ${ }^{230} \mathrm{Th}$ are from 9.0 to 200.0 Bq kg${ }^{-1}$ and the leached fractions from 3.0 to $98.0 \mathrm{~Bq} \mathrm{~kg}^{-1}$. The total ${ }^{226} \mathrm{Ra}$ specific activities are in the range from 15.0 to $179.0 \mathrm{~Bq} \mathrm{~kg}^{-1}$, and those from leaching are from 8.0 to 193.0 $\mathrm{Bq} \mathrm{kg}^{-1}$ (although the highest leaching result is nominally higher than the highest result from gamma spectrometry, the two results are essentially the same within measurement error). The specific activities of the radionuclides extracted by leaching, relative to total dissolution, are in the range of $30-70 \%$ for the uranium, $30-75 \%$ for the thorium and 30 $100 \%$ of the radium. This disparity of the radionuclide content may reflect different source terms, as well as differing associations with secondary minerals and organic matter content along the valley. 


\subsubsection{Fractionation of the radionuclides}

\subsubsection{1 $\left({ }^{234} \mathrm{U} /{ }^{238} \mathrm{U}\right)$ activity ratios}

For the total dissolution (Fig. 2), all of the sediments from Edale, except S8 and S23, show ${ }^{234} \mathrm{U} /{ }^{238} \mathrm{U}>1$, within the error, and an average ratio of 1.1. For the acid leaching (Fig. 3) the mean ${ }^{234} \mathrm{U} /{ }^{238} \mathrm{U}$ ratio is 1.2 , as might be expected given the origins of disequilibrium.

These results cannot be explained by weathering processes only, since the expected value of this ratio is less than unity in sediment produced by simple leaching of detrital rock fragments or minerals in rivers, and greater than unity in water ${ }^{22,23}$. However, similar results have been published from previous studies of sediments and suspended matter from rivers in Eastern England ${ }^{4}$, in organic-rich sediments from rivers in Sweden ${ }^{11}$ and in lowland rivers of the Amazon ${ }^{24}$. The likely explanation is adsorption of a uranium component fraction with ${ }^{234} \mathrm{U} /{ }^{238} \mathrm{U}>1$ from the water column onto the sediments' mineral surfaces. It has been demonstrated experimentally that some minerals such as clays or iron/manganese oxide phases are efficient at removing radionuclides from the soluble phase ${ }^{25}$. The organic matter content may also contribute significantly to chemical fractionation between uranium and its long-lived daughters ${ }^{26}$. Therefore, the ${ }^{234} \mathrm{U}$ and ${ }^{238} \mathrm{U}$ activities in Edale stream sediments may reflect the influence of both reactive secondary minerals and organic matter.

\subsubsection{2 $\left({ }^{230} \mathrm{Th} /{ }^{238} \mathrm{U}\right)$ activity ratios}

If weathering processes primarily drive $\mathrm{U}$-series fractionation, the ${ }^{230} \mathrm{Th} /{ }^{238} \mathrm{U}$ activity ratio will expected to be $>1$ in sediments, produced by simple leaching of detrital rock fragments or minerals in rivers, and $<1$ in river water ${ }^{4,22}$. For the total dissolutions, only four samples (E1, E8, E10 and E22) show a clear ${ }^{230} \mathrm{Th} /{ }^{238} \mathrm{U}>1$ (Fig. 4), while five samples of the leaching analyses (E1, E13, E17, E24 and E25) display ${ }^{230} \mathrm{Th} /{ }^{238} \mathrm{U}>1$ (Fig. 5). This trend is not common, but similar effects have been seen in samples of colloids and particulate matter from lowland rivers of the Amazon basin, and the Kalix River in Sweden ${ }^{24,27}$. Preferential complexation of thorium with dissolved organic matter, which enhances its mobility, and 
hence leads to depletion in sediments compared to uranium, may be the cause ${ }^{4}$. As the disequilibrium between ${ }^{238} \mathrm{U}$ and ${ }^{234} \mathrm{U}$ can be at least partly attributed to the organic matter content of Edale valley sediments, a similar effect could be expected for the ${ }^{230} \mathrm{Th} /{ }^{238} \mathrm{U}$ activity ratio.

\subsubsection{3 $\left({ }^{226} \mathrm{Ra} /{ }^{238} \mathrm{U}\right)$ activity ratios}

If the impact of organic matter, micro-organism, colloids and minerals is not considered, mobility of Ra, Th and $\mathrm{U}$ has been reported to be in the order: $\mathrm{U}>\mathrm{Ra}>\mathrm{Th}{ }^{1}$. From the total analyses and the acid leaching results, given in Tables 3 and 4 respectively, all of the streams in the valley, except E8, E12 and E13, exhibit ${ }^{226} \mathrm{Ra} /{ }^{238} \mathrm{U}$ activity ratios > 1, indicating enrichment of the daughter over the parent uranium. Elevated ${ }^{226} \mathrm{Ra} /{ }^{238} \mathrm{U}$ ratios, up to 9, have been reported in organic-rich soil from Cronamuck Valley, Ireland ${ }^{28}$. This is consistent with the expected pattern of mobility and may reflect efficient adsorption of ${ }^{226} \mathrm{Ra}$ onto organic matter and mineral surfaces, comparable to the possible oxidation and greater mobility of the uranium $^{29}$. The streams running near to the landslips (e.g. S3, S4, S5, S7 and S24) on the southern side of the valley (Fig. 1) seem to show higher radium contents relative to the ${ }^{238} \mathrm{U}$ parent. The ${ }^{226} \mathrm{Ra} /{ }^{238} \mathrm{U}$ disequilibrium was greater in the aqua regia leaches, compared with the total dissolutions for all streams except S8, S12 and S13. The results suggest that, both ${ }^{226} \mathrm{Ra}$ and ${ }^{238} \mathrm{U}$ are affected by adsorption processes. However, adsorption on sediment is more efficient for the divalent ion radium through precipitation and ion exchange with calcium, so increasing ${ }^{226} \mathrm{Ra}$ content relative to ${ }^{238} \mathrm{U}^{30}$.

\subsection{4 ${ }^{234} \mathrm{U} /{ }^{238} \mathrm{U}$ and ${ }^{230} \mathrm{Th} /{ }^{238} \mathrm{U}$ isotopic ratio diagram}

In order to examine the hypothesis that some Edale sediments do not conform to the simple weathering processes example in U-series geochemical fractionation, plots of $\left({ }^{230} \mathrm{Th} /{ }^{238} \mathrm{U}\right)$ against $\left({ }^{234} \mathrm{U} /{ }^{238} \mathrm{U}\right)$ activity ratios of the total and the leached fractions are shown in the supporting information (Fig. S1 and Fig. S2) In simple leaching during weathering, it is not 
possible to attain certain isotopic ratios in solid components such as sediments or suspended matter ${ }^{8}$. These specific areas are identified as "Complex zones" and have been coloured in grey, as in Figures S1 and S2. However, plotting the data obtained for both total dissolution and aqua regia leaching of the Edale sediments revealed that the ${ }^{230} \mathrm{Th} /{ }^{238} \mathrm{U}$ and ${ }^{234} \mathrm{U} /{ }^{238} \mathrm{U}$ ratios fall in the complex zones. Within the complex zone, some points from total dissolution plotted in the region, representing depletion in ${ }^{234} \mathrm{U}$ and ${ }^{230} \mathrm{Th}$ (Fig. S1), while majority of the aqua regia leach results were in the region enriched in ${ }^{234} \mathrm{U}$ and ${ }^{230} \mathrm{Th}$ (Fig. S2). This is consistent with the idea that radionuclides associated with the sediment fractions other than the residual are more likely to be adsorbed from the water onto the sediment surfaces. Such complex behaviour has been observed previously ${ }^{7}$ and, again, suggests the need for alternative hypotheses to explain this behaviour other than the simple weathering suggestion.

\subsubsection{Hierarchical cluster analysis}

Hierarchical cluster analysis (HCA) is a multivariate analysis technique designed to categorize relatively similar samples, where there may not be a simple discriminator, into separate groups. The technique has been recently used to identify associations between sampling locations and a range of variables for river sediments ${ }^{31,32}$.

Prior to the calculations, all data were Z-scored, so that all variables carried equal weight in the analysis. Z-scores measure the distance of the raw data from the mean of that variable in terms of the standard deviation. The $\mathrm{z}$-score $\left(\mathrm{Z}_{\mathrm{i}}\right)$ is given by,

$$
Z i=\left|\frac{x_{i}-\bar{x}}{S}\right|
$$

where $\bar{x}$ is the mean value, and $\mathrm{S}$ is the standard deviation of the whole population.

Following Z-scoring, all of the samples were plotted as points in 5-dimensional hyperspace, where each (Z-scored) variable is used to define a coordinate, i.e., if a sample has variable values of $\mathrm{v}, \mathrm{w}, \mathrm{x}, \mathrm{y}$ and $\mathrm{z}$, then the coordinate of the sample in hyperspace will be $(\mathrm{v}, \mathrm{w}, \mathrm{x}, \mathrm{y}, \mathrm{z})$. 
The technique assumes that the difference between two samples increases with the distance between the samples in hyperspace. The samples are clustered together, such that, at each step, the sum of squares of the differences between the samples and their cluster centres is minimised. In the first step, the two closest samples are linked. In the next step, another sample can join the first cluster or two different samples can combine to initiate a second, depending upon which action will minimise the sum of the square of the distances. This procedure is repeated until, at the final stage, all of the samples are linked together.

The similarity or distance between samples is measured by standard procedures, such as Euclidean distance, which is an extension of Pythagoras' theorem to a multidimensional space. For the Euclidean distance, the square of the distances between two samples in a multidimensional space is equal to the sum of squared differences of their coordinates ${ }^{33}$. The Euclidean metric is that used to measure the distance between points in real space. However, other metrics are available, such as City block, where the overall distance between points is the linear sum of the differences in their coordinates. In this work, separate cluster analyses were performed with both distance metrics, since if a result is real and significant, then it should be independent of the distance metric.

Mahalanobis distance is a statistical approach to identifying outliers within a set of multivariable data. It measures the distance of a variable from the centroid (multidimensional mean) of a distribution, given the covariance (multidimensional variance) of the distribution 33.

For the total dissolution results, two outliers (E8 and E23) of the 25 sediment samples from Edale valley were detected and excluded, since these outliers could not be assigned to any of the four groups identified by the dendrogram, as shown in the supporting information Fig. S3. In total, 23 sediment samples were classified based on five variables: $\left[{ }^{238} \mathrm{U}\right],\left[{ }^{234} \mathrm{U}\right],\left[{ }^{230} \mathrm{Th}\right]$, 
$\left[{ }^{226} \mathrm{Ra}\right]$ and loss on ignition. The groups were tested to examine any overlap between them. The results revealed that the groups are separated clearly to five clusters.

The average concentrations of the samples in the five groups and their members are given in the supporting information (Table S1). The samples clustered in group T1 (E3, E6, E9, E10, E13, E14, E15, E20 and E21) represent samples with the lowest radionuclides and organic matter contents. The samples in group T2 (E2, E5, E11, and E12) have a mean radionuclide twice that of group T1, as well as a higher organic matter content. Group T3 (E1, E4 and E22) has radionuclide concentrations about three times the background level (T1) although the organic matter content is similar to that of group T2. Group T4 (E19, E24 and E25) shows the highest organic matter content, but the concentrations of ${ }^{238} \mathrm{U},{ }^{234} \mathrm{U}$ and ${ }^{226} \mathrm{Ra}$ are same as group T3. The locations in group T5 (E7, E16, E17 and E18) are rich in organic matter, as group T4; however, the radionuclide concentrations are lower, comparable to group T2.

For the results from aqua regia leaching, two outliers (again samples E8 and E23) of the 25 sediment samples from Edale valley were excluded, since they could not be assigned to any of the four groups identified by cluster analysis (supporting information Fig.S4). In total, 23 sediment samples were classified based on the same five variables as before. The groups were tested to examine any overlap between them but they are separated clearly, although groups L1 and L3 are close.

The average concentrations of the samples in the four groups and their members are given in the supporting information Table S2. The samples clustered in group L1 (E3, E5, E6, E9, E10, E11, E13, E14, E15, E20 and E21) represent samples with lower radionuclide contents, as well as low organic matter content. Group L3 (E7, E16 and E17) has radionuclide concentrations that are very similar to group L1, and these two groups have only separated because of differences in organic matter content. The samples in group L2 (E1, E2, E12, and E18) show higher radionuclide concentrations, while Group L4 (E19, E22, E24 and E25) 
shows the highest concentrations of ${ }^{238} \mathrm{U},{ }^{234} \mathrm{U}$ and ${ }^{226} \mathrm{Ra}$, as well as high organic matter content. The sample E4 was separated out as a single group, because of its higher radium content. In addition, the outliers (E8 and E23) contain high radionuclide concentrations and organic matter.

Comparing the cluster analyses from aqua regia leaching and total dissolution, revealed that the same two samples, E8 and E23, were consistently eliminated as outliers. The obvious difference is that an additional group is separated out from the total dissolution results compared with those from aqua regia leaching.

The average values of the radionuclide concentrations in groups T1 (E3, E6, E9, E10, E13, E14, E15, E20 and E21) and L1 (E3, E5, E6, E9, E10, E11, E13, E14, E15, E20 and E21), from both aqua regia leaching and total dissolution data, represent background levels of the radionuclides. Organic matter content is also low (4\%) in both groups. This suggests that, if the sample contains nothing much in the leach, it will contain nothing much in the total.

The average content of radionuclides of groups L4 (E19, E22, E24 and E25) and T3 (E1, E4 and E22), from both aqua regia leaching and total dissolution data, show the highest values among the groups. On average, group L4 shows high organic matter (14\%) compared with that of group T3 (6\%). The average concentration of the radionuclides in another group, T4 (E19, E24 and E25) is same as T3, with a difference in organic content (OM 16\%). The similarity in the average radionuclides in $\mathrm{T} 3$ and $\mathrm{T} 4$ suggests an association of the radionuclides with the primary minerals. However, the radium content in T3, T4 and L4, despite the difference in the extraction method, suggests a complex mechanism in binding/retaining radium. 
On average, relatively low concentrations of radionuclides were observed in groups T5 (E7, E16, E17 and E18) and L3 (S7, S16 and S17), in association with high organic matter (15\% and $17 \%$ respectively). However, while organic matter content appears to bear some relationship to radionuclide content, it is not a good discriminator, as illustrated by groups L2 (E1, E2, E12 and E18) and T2 (E2, E5, E11 and E12), where both groups have a relatively low OM content (7\% and 5\% respectively) but nevertheless have high radionuclide activities.

Comparison of the cluster analysis results for both aqua regia leaching and total dissolution data with the sampling locations in Fig. 1, shows that none of the groups identified by cluster analysis has all of its members gathered in one area of the valley. However, samples with the highest radionuclide concentrations from aqua regia leaching (E19, E22, E24 and E25) are located to the south of the river, and three of them are adjacent, in the south-east of the sampling area.

For the total dissolution results, groups T3 and T4 (which represent, relatively, the higher activity samples) are also concentrated on the southern side of the valley, generally close to landslips. In particular, the samples with higher radium values are located in streams that are likely to receive runoff water from the slips. It is possible that the landslips have exposed relatively fresh and/or uranium-rich material higher up the valley sides, and that radium is leaching from that material and being transported down the streams, where it is sorbing onto the stream sediments. This would also explain the ${ }^{234} U /{ }^{238} U$ ratios $>1$, since ${ }^{234} U$ would be expected to leach preferentially from the material exposed by the landslips, leading to higher sorbed concentrations in the stream sediments.

\subsection{Conclusions}

U-series isotopes have been measured in stream sediments, applying two dissolution methods, in an effort to understand chemical weathering and physical erosion in Edale. This study showed considerable variability in radionuclide concentrations, even over a fairly small 
geographical area, albeit a geologically complex one. This variation suggests an interplay of the parent materials, organic matter and secondary minerals in the sediments. The daughter/parent isotopic ratios revealed complex U-series disequilibria. Adsorption of uranium onto mineral surfaces and/or organic matter and migration of thorium complexed by organic matter are likely to be major impacts on these disequilibria. Plots of $\left({ }^{234} \mathrm{U} /{ }^{238} \mathrm{U}\right)$ against $\left({ }^{230} \mathrm{Th} /{ }^{238} \mathrm{U}\right)$ indicate that weathering processes in Edale are not simple. Cluster analysis provides insight into radionuclide behaviour and suggests a relationship between the landslips in the Noe valley and the stream sediment isotope concentrations. It is possible that uranium-containing material has been exposed by the slips, and that ${ }^{226} \mathrm{Ra}$ and ${ }^{234} \mathrm{U}$ are being released into the runoff water, and then becoming sorbed onto the stream sediments.

\section{Acknowledgement}

The authors are grateful for financial support from the Islamic Development Bank (IDB), Jeddah, Saudi Arabia and are also acknowledge support from the UK Natural Environment Research Council (NERC). 


\section{References}

1. M. Ivanovich and R. S. Harmon, in Uranium-series disequilibrium: applications to earth, marine, and environmental sciences, Oxford University Press, New York, Editon edn., 1992.

2. M. Pekala, J. D. Kramers and H. N. Waber, Applied Radiation and Isotopes, 2010, 68, 984992.

3. J. Michel, Geochimica et Cosmochimica Acta, 1984, 48, 1249-1255.

4. A. J. Plater, M. Ivanovich and R. E. Dugdale, Applied Geochemistry, 1992, 7, 101-110.

5. F. Chabaux, J. Riotte and O. Dequincey, in Reviews in Mineralogy and Geochemistry, Editon edn., 2003, vol. 52, 533- 576.

6. R. J. Murphy, J. J. Lenhart and B. D. Honeyman, Colloids and Surfaces A: Physicochemical and Engineering Aspects, 1999, 157, 47-62.

7. A. Dosseto, B. Bourdon and S. P. Turner, Earth and Planetary Science Letters, 2008, 265, 117.

8. F. Chabaux, B. Bourdon and J. Riotte, in Radioactivity in the Environment, Elsevier, Editon edn., 2008, vol. Volume 13, pp. 49-104.

9. P. A. E. Pogge von Strandmann, K. W. Burton, D. Porcelli, R. H. James, P. van Calsteren and S.

R. Gislason, Earth and Planetary Science Letters, 2011, 301, 125-136.

10. G. Suresh, V. Ramasamy, V. Meenakshisundaram, R. Venkatachalapathy and V. Ponnusamy, Journal of Environmental Radioactivity, 2011, 102, 370-377.

11. P. S. Andersson, D. Porcelli, G. J. Wasserburg and J. Ingri, Geochimica et Cosmochimica Acta, 1998, 62, 385-392.

12. U. Noseck, E. L. Tullborg, J. Suksi, M. Laaksoharju, V. Havlová, M. A. Denecke and G. Buckau, Applied Geochemistry, 2012, 27, 490-500.

13. M. B. Andersen, Y. Erel and B. Bourdon, Geochimica et Cosmochimica Acta, 2009, 73, 41244141.

14. N. Vigier, K. W. Burton, S. R. Gislason, N. W. Rogers, S. Duchene, L. Thomas, E. Hodge and B. Schaefer, Earth and Planetary Science Letters, 2006, 249, 258-273.

15. C. Galindo, L. Mougin, S. Fakhi, A. Nourreddine, A. Lamghari and H. Hannache, Journal of Environmental Radioactivity, 2007, 92, 41-54.

16. S. H. Bottrell, Environmental Geochemistry and Health, 1993, 15, 21-25.

17. N. Dixon and E. Brook, Landslides, 2007, 4, 137-147.

18. J. D. Peacock and K. Taylor, NERC Bulletin of the Geological Survey of Great Britain No. 25, 1966, London.

19. T. D. Ford, In Sylvester-Bradley, P. C. and Ford, T. D., The Geology of the East Midlands, 1968, Leicester University Press, Bath.

20. O. J. Marsden, F. R. Livens, J. P. Day, L. K. Fifield and P. S. Goodall, Analyst, 2001, 126, 633636.

21. H. E. Carter, P. Warwick, J. Cobb and G. Longworth, Analyst, 1999, 124, 271-274.

22. N. Vigier, B. Bourdon, S. Turner and C. J. Allegre, Earth and Planetary Science Letters, 2001, 193, 549-563.

23. P. A. E. Pogge von Strandmann, K. W. Burton, R. H. James, P. van Calsteren, S. R. Gislason and F. Mokadem, Earth and Planetary Science Letters, 2006, 251, 134-147.

24. A. Dosseto, B. Bourdon, J. Gaillardet, C. J. Allègre and N. Filizola, Geochimica et Cosmochimica Acta, 2006, 70, 71-89.

25. M. C. Duff, J. U. Coughlin and D. B. Hunter, Geochimica et Cosmochimica Acta, 2002, 66, 3533-3547.

26. A. Dosseto, B. Bourdon, J. Gaillardet, L. Maurice-Bourgoin and C. J. Allegre, Earth and Planetary Science Letters, 2006, 248, 759-771.

27. D. Porcelli, P. S. Andersson, M. Baskaran and G. J. Wasserburg, Geochimica et Cosmochimica Acta, 2001, 65, 2439-2459.

28. M. Dowdall and J. O'Dea, Journal of Environmental Radioactivity, 2002, 59, 91-104. 
29. P. Blanco, F. V. Tome and J. C. Lozano, Journal of Environmental Radioactivity, 2005, 79, 315330.

30. J. Lehto and X. Hou, in Chemistry and Analysis of Radionuclides, Wiley-VCH Verlag GmbH \& Co. KGaA, Editon edn., 2010, pp. 99-122.

31. A. Gielar, E. Helios-Rybicka, S. Möller and J. W. Einax, Applied Geochemistry, 2012, 27, 15401545.

32. M. T. Guillén, J. Delgado, S. Albanese, J. M. Nieto, A. Lima and B. De Vivo, Journal of Geochemical Exploration, 2012, doi: 10.1016/j.gexplo.2012.1006.1009.

33. M. G. Kim, Communications in Statistics - Theory and Methods, 2000, 29, 1511-1526. 
Table 1 The measured, the recommended and the leached values of ${ }^{226} \mathrm{Ra}$ and ${ }^{238} \mathrm{U}$ in IAEA314 stream sediment reference material

\begin{tabular}{|l|l|l|}
\hline & ${ }^{226} \mathrm{Ra} \mathrm{Bq} \cdot \mathrm{kg}^{-1}$ & ${ }^{238} \mathrm{U} \mathrm{mg} \cdot \mathrm{kg}^{-1}$ \\
\hline Measured & $774 \pm 24$ & $58 \pm 1.1$ \\
\hline Recommended & 732 & 56.8 \\
\hline $95 \%$ Confidence interval & $678-787$ & $52.9-60.7$ \\
\hline Value from leaching using aqua regia & $490 \pm 1.5$ & $43 \pm 1.6$ \\
\hline$\%$ of the leached fraction in the recommended value & $67 \%$ & $76 \%$ \\
\hline
\end{tabular}


Table 2 Edale sediment sample coordinates, loss on ignition and mineralogy

\begin{tabular}{|c|c|c|c|}
\hline Sample ID & Coordinates & Loss on ignition \% & Mineralogy \\
\hline E1 & $53^{0} 21.558^{\prime} \mathrm{N} ; 1^{0} 50.107^{\prime} \mathrm{W}$ & 5 & $\mathrm{Q}, \mathrm{M}, \mathrm{A}$ \\
\hline E2 & $53^{0} 21.549^{\prime} \mathrm{N} ; 1^{0} 50.042^{\prime} \mathrm{W}$ & 7 & $\mathrm{Q}, \mathrm{M}, \mathrm{A}$ \\
\hline E3 & $53^{0} 21.526^{\prime} \mathrm{N} ; 1^{0} 49.722^{\prime} \mathrm{W}$ & 4 & $\mathrm{Q}, \mathrm{M}, \mathrm{A}$ \\
\hline $\mathrm{E} 4$ & $53^{0} 21.518^{\prime} \mathrm{N} ; 1^{0} 49.561^{\prime} \mathrm{W}$ & 6 & $\mathrm{Q}, \mathrm{M}, \mathrm{A}$ \\
\hline E5 & $53^{0} 21.513^{\prime} \mathrm{N} ; 1^{0} 49.567^{\prime} \mathrm{W}$ & 6 & $\mathrm{Q}, \mathrm{M}, \mathrm{A}$ \\
\hline E6 & $53^{0} 21.518^{\prime} \mathrm{N} ; 1^{0} 49.276^{\prime} \mathrm{W}$ & 5 & $\mathrm{Q}, \mathrm{M}, \mathrm{A}, \mathrm{K}$ \\
\hline E7 & $53^{0} 21.508^{\prime} \mathrm{N} ; 1^{0} 49.187^{\prime} \mathrm{W}$ & 14 & $\mathrm{Q}$ \\
\hline E8 & $53^{0} 21.475^{\prime} \mathrm{N} ; 1^{0} 48.903^{\prime} \mathrm{W}$ & 9 & $\mathrm{Q}, \mathrm{M}, \mathrm{K}, \mathrm{A}$ \\
\hline E9 & $53^{0} 21.952^{\prime} \mathrm{N} ; 1^{0} 49.350^{\prime} \mathrm{W}$ & 5 & $\mathrm{Q}, \mathrm{A}$ \\
\hline E10 & $53^{0} 21.895^{\prime} \mathrm{N} ; 1^{0} 49.458^{\prime} \mathrm{W}$ & 6 & $\mathrm{Q}, \mathrm{A}$, \\
\hline E11 & $53^{0} 21.730^{\prime} \mathrm{N} ; 1^{0} 49.711^{\prime} \mathrm{W}$ & 5 & $\mathrm{Q}, \mathrm{A}$ \\
\hline E12 & $53^{0} 21.696^{\prime} \mathrm{N} ; 1^{0} 49.840^{\prime} \mathrm{W}$ & 3 & $\mathrm{Q}, \mathrm{A}$ \\
\hline E13 & $53^{0} 22.108^{\prime} \mathrm{N} ; 1^{0} 48.893^{\prime} \mathrm{W}$ & 3 & $\mathrm{Q}, \mathrm{A}$ \\
\hline E14 & $53^{0} 22.221^{\prime} \mathrm{N} ; 1^{0} 48.488^{\prime} \mathrm{W}$ & 3 & $\mathrm{Q}, \mathrm{A}$ \\
\hline E15 & $53^{0} 22.178^{\prime} \mathrm{N} ; 1^{0} 48.350^{\prime} \mathrm{W}$ & 3 & $\mathrm{Q}, \mathrm{A}$ \\
\hline E16 & $53^{0} 22.239^{\prime} \mathrm{N} ; 1^{0} 47.947^{\prime} \mathrm{W}$ & 18 & $\mathrm{Q}, \mathrm{A}$ \\
\hline E17 & $53^{0} 22.211^{\prime} \mathrm{N} ; 1^{0} 48.009^{\prime} \mathrm{W}$ & 17 & $\mathrm{Q}, \mathrm{A}$ \\
\hline E18 & $53^{0} 21.563^{\prime} \mathrm{N} ; 1^{0} 50.471^{\prime} \mathrm{W}$ & 11 & $\mathrm{Q}, \mathrm{A}$ \\
\hline E19 & $53^{0} 21.648^{\prime} \mathrm{N} ; 1^{0} 50.660^{\prime} \mathrm{W}$ & 19 & $\mathrm{Q}, \mathrm{A}$ \\
\hline E20 & $53^{0} 21.882^{\prime} \mathrm{N} ; 1^{0} 50.842^{\prime} \mathrm{W}$ & 2 & $\mathrm{Q}, \mathrm{A}$ \\
\hline E21 & $53^{0} 21.875^{\prime} \mathrm{N} ; 1^{0} 50.912^{\prime} \mathrm{W}$ & 4 & $\mathrm{Q}, \mathrm{K}, \mathrm{A}$ \\
\hline E22 & $53^{0} 21.769^{\prime} \mathrm{N} ; 1^{0} 48.406^{\prime} \mathrm{W}$ & 6 & $\mathrm{Q}, \mathrm{A}$ \\
\hline E23 & $53^{0} 21.735^{\prime} \mathrm{N} ; 1^{0} 48.678^{\prime} \mathrm{W}$ & 11 & $\mathrm{Q}, \mathrm{A}$ \\
\hline E24 & $53^{0} 21.783^{\prime} \mathrm{N} ; 1^{0} 48.303^{\prime} \mathrm{W}$ & 15 & $\mathrm{Q}$ \\
\hline E25 & $53^{0} 21.798^{\prime} \mathrm{N} ; 1^{0} 48.237^{\prime} \mathrm{W}$ & 15 & $\mathrm{Q}, \mathrm{M}, \mathrm{A}$ \\
\hline
\end{tabular}

( $Q$ = Quartz, $M=$ Muscovite, $K=$ Kaolinite, $A=$ Albite $)$ 
Table 3 Specific activities concentrations (Bq. $\mathrm{kg}^{-1}$ dry weight) of the total ${ }^{238} \mathrm{U},{ }^{234} \mathrm{U},{ }^{230} \mathrm{Th}$, ${ }^{226} \mathrm{Ra}$ and ${ }^{234} \mathrm{U} /{ }^{238} \mathrm{U},{ }^{230} \mathrm{Th} /{ }^{238} \mathrm{U},{ }^{226} \mathrm{Ra} /{ }^{238} \mathrm{U}$ activity ratios of sediments from the Edale valley ( $\pm 1 \sigma$ counting statistics uncertainties)

\begin{tabular}{|c|c|c|c|c|c|c|c|}
\hline ID & ${ }^{238} \mathrm{U}$ & ${ }^{234} \mathbf{U}$ & ${ }^{230} \mathrm{Th}$ & ${ }^{226} \mathrm{Ra}$ & ${ }^{234} \mathbf{U} /{ }^{238} \mathbf{U}$ & ${ }^{230} \mathrm{Th} /{ }^{238} \mathrm{U}$ & ${ }^{226} \mathrm{Ra} /{ }^{238} \mathrm{U}$ \\
\hline E1 & $73 \pm 4$ & $75 \pm 4$ & $30 \pm 4$ & $71 \pm 2$ & $1.03 \pm 0.07$ & $0.41 \pm 0.15$ & $0.97 \pm 0.07$ \\
\hline E2 & $43 \pm 4$ & $49 \pm 4$ & $46 \pm 5$ & $53 \pm 2$ & $1.14 \pm 0.14$ & $1.07 \pm 0.36$ & $1.23 \pm 0.20$ \\
\hline E3 & $24 \pm 3$ & $24 \pm 3$ & $20 \pm 4$ & $45 \pm 2$ & $1.00 \pm 0.16$ & $0.83 \pm 0.37$ & $1.88 \pm 0.19$ \\
\hline E4 & $30 \pm 3$ & $32 \pm 3$ & $31 \pm 5$ & $131 \pm 15$ & $1.07 \pm 0.16$ & $1.03 \pm 0.44$ & $4.37 \pm 0.69$ \\
\hline E5 & $34 \pm 3$ & $38 \pm 3$ & $34 \pm 4$ & $66 \pm 3$ & $1.12 \pm 0.14$ & $1.00 \pm 0.36$ & $1.94 \pm 0.13$ \\
\hline E6 & $24 \pm 3$ & $27 \pm 3$ & $19 \pm 4$ & $29 \pm 1$ & $1.13 \pm 0.17$ & $0.79 \pm 0.37$ & $1.21 \pm 0.17$ \\
\hline E7 & $25 \pm 3$ & $29 \pm 3$ & $19 \pm 4$ & $57 \pm 3$ & $1.16 \pm 0.17$ & $0.76 \pm 0.35$ & $2.28 \pm 0.11$ \\
\hline E8 & $81 \pm 5$ & $72 \pm 4$ & $56 \pm 6$ & $86 \pm 3$ & $0.90 \pm 0.07$ & $0.69 \pm 0.24$ & $1.06 \pm 0.07$ \\
\hline E9 & $22 \pm 3$ & $24 \pm 3$ & $45 \pm 4$ & $36 \pm 1$ & $1.09 \pm 0.20$ & $2.05 \pm 0.68$ & $1.64 \pm 0.16$ \\
\hline E10 & $36 \pm 4$ & $41 \pm 4$ & $20 \pm 4$ & $39 \pm 2$ & $1.14 \pm 0.16$ & $0.56 \pm 0.24$ & $1.08 \pm 0.09$ \\
\hline E11 & $46 \pm 4$ & $45 \pm 4$ & $37 \pm 5$ & $70 \pm 4$ & $0.98 \pm 0.12$ & $0.80 \pm 0.32$ & $1.52 \pm 0.09$ \\
\hline E12 & $35 \pm 3$ & $38 \pm 3$ & $33 \pm 5$ & $61 \pm 3$ & $1.09 \pm 0.14$ & $0.94 \pm 0.38$ & $1.74 \pm 0.10$ \\
\hline E13 & $19 \pm 2$ & $21 \pm 2$ & $21 \pm 4$ & $15 \pm 1$ & $1.11 \pm 0.17$ & $1.11 \pm 0.48$ & $0.79 \pm 0.19$ \\
\hline E14 & $18 \pm 2$ & $18 \pm 2$ & $14 \pm 3$ & $29 \pm 1$ & $1.00 \pm 0.19$ & $0.78 \pm 0.39$ & $1.61 \pm 0.16$ \\
\hline E15 & $9 \pm 2$ & $12 \pm 2$ & $9 \pm 3$ & $18 \pm 1$ & $1.33 \pm 0.28$ & $1.00 \pm 0.54$ & $2.00 \pm 0.25$ \\
\hline E16 & $24 \pm 3$ & $23 \pm 2$ & $25 \pm 5$ & $40 \pm 2$ & $0.96 \pm 0.15$ & $1.04 \pm 0.47$ & $1.67 \pm 0.12$ \\
\hline E17 & $41 \pm 3$ & $53 \pm 4$ & $38 \pm 6$ & $44 \pm 2$ & $1.29 \pm 0.14$ & $0.93 \pm 0.36$ & $1.07 \pm 0.14$ \\
\hline E18 & $33 \pm 3$ & $47 \pm 4$ & $27 \pm 4$ & $48 \pm 2$ & $1.42 \pm 0.18$ & $0.82 \pm 0.33$ & $1.45 \pm 0.14$ \\
\hline E19 & $64 \pm 4$ & $59 \pm 4$ & $33 \pm 4$ & $107 \pm 4$ & $0.92 \pm 0.08$ & $0.52 \pm 0.19$ & $1.67 \pm 0.14$ \\
\hline E20 & $14 \pm 2$ & $15 \pm 2$ & $19 \pm 4$ & $36 \pm 2$ & $1.07 \pm 0.20$ & $1.36 \pm 0.64$ & $2.57 \pm 0.21$ \\
\hline E21 & $20 \pm 2$ & $24 \pm 3$ & $20 \pm 4$ & $33 \pm 2$ & $1.20 \pm 0.19$ & $1.00 \pm 0.45$ & $1.65 \pm 0.28$ \\
\hline E22 & $86 \pm 5$ & $84 \pm 5$ & $64 \pm 7$ & $119 \pm 4$ & $0.98 \pm 0.08$ & $0.74 \pm 0.26$ & $1.38 \pm 0.10$ \\
\hline E23 & $184 \pm 8$ & $170 \pm 8$ & $200 \pm 13$ & $179 \pm 8$ & $0.92 \pm 0.06$ & $1.09 \pm 0.28$ & $0.97 \pm 0.06$ \\
\hline E24 & $48 \pm 4$ & $65 \pm 4$ & $56 \pm 7$ & $104 \pm 4$ & $1.35 \pm 0.14$ & $1.17 \pm 0.41$ & $2.17 \pm 0.22$ \\
\hline E25 & $51 \pm 4$ & $63 \pm 4$ & $38 \pm 5$ & $89 \pm 4$ & $1.24 \pm 0.12$ & $0.75 \pm 0.29$ & $1.75 \pm 0.17$ \\
\hline
\end{tabular}


Table 4 Specific activities concentrations (Bq. $\mathrm{kg}^{-1}$ dry weight) of the leached ${ }^{238} \mathrm{U},{ }^{234} \mathrm{U}$, ${ }^{230} \mathrm{Th},{ }^{226} \mathrm{Ra}$ and $\left({ }^{234} \mathrm{U} /{ }^{238} \mathrm{U}\right),\left({ }^{230} \mathrm{Th} /{ }^{238} \mathrm{U}\right),\left({ }^{226} \mathrm{Ra} /{ }^{238} \mathrm{U}\right)$ activity ratios of sediments from the Edale valley ( $\pm 1 \sigma$ counting statistics uncertainties)

\begin{tabular}{|c|c|c|c|c|c|c|c|}
\hline ID & ${ }^{238} \mathrm{U}$ & ${ }^{234} \mathbf{U}$ & ${ }^{230} \mathrm{Th}$ & ${ }^{226} \mathrm{Ra}$ & ${ }^{234} \mathrm{U}^{238} \mathrm{U}$ & ${ }^{230} \mathrm{Th} /{ }^{238} \mathrm{U}$ & ${ }^{226} \mathrm{Ra} /{ }^{238} \mathrm{U}$ \\
\hline E1 & $25 \pm 2$ & $31 \pm 3$ & $18 \pm 2$ & $56 \pm 2$ & $1.24 \pm 0.15$ & $0.72 \pm 0.23$ & $2.24 \pm 0.18$ \\
\hline E2 & $19 \pm 1$ & $25 \pm 2$ & $28 \pm 3$ & $53 \pm 4$ & $1.32 \pm 0.14$ & $1.47 \pm 0.46$ & $2.79 \pm 0.02$ \\
\hline $\mathbf{E 3}$ & $7 \pm 1$ & $9 \pm 1$ & $6 \pm 1$ & $17 \pm 1$ & $1.29 \pm 0.25$ & $0.86 \pm 0.40$ & $2.43 \pm 0.38$ \\
\hline E4 & $12 \pm 1$ & $14 \pm 1$ & $12 \pm 1$ & $180 \pm 12$ & $1.17 \pm 0.09$ & $1.00 \pm 0.27$ & $15.00 \pm 0.81$ \\
\hline E5 & $14 \pm 1$ & $18 \pm 1$ & $19 \pm 1$ & $21 \pm 1$ & $1.29 \pm 0.13$ & $1.33 \pm 0.35$ & $1.50 \pm 0.10$ \\
\hline E6 & $7 \pm 1$ & $8 \pm 1$ & $7 \pm 1$ & $13 \pm 1$ & $1.14 \pm 0.25$ & $1.00 \pm 0.43$ & $1.86 \pm 0.32$ \\
\hline $\mathbf{E 7}$ & $7 \pm 1$ & $8 \pm 1$ & $6 \pm 1$ & $14 \pm 1$ & $1.14 \pm 0.23$ & $0.86 \pm 0.41$ & $2.00 \pm 0.33$ \\
\hline E8 & $50 \pm 6$ & $49 \pm 6$ & $43 \pm 6$ & $41 \pm 2$ & $0.98 \pm 0.16$ & $0.86 \pm 0.32$ & $0.82 \pm 0.09$ \\
\hline E9 & $10 \pm 1$ & $12 \pm 1$ & $13 \pm 1$ & $14 \pm 1$ & $1.20 \pm 0.09$ & $1.30 \pm 0.34$ & $1.40 \pm 0.07$ \\
\hline E10 & $17 \pm 1$ & $20 \pm 1$ & $20 \pm 1$ & $19 \pm 1$ & $1.18 \pm 0.12$ & $1.18 \pm 0.27$ & $1.12 \pm 0.07$ \\
\hline E11 & $9 \pm 1$ & $10 \pm 1$ & $19 \pm 2$ & $24 \pm 1$ & $1.11 \pm 0.15$ & $2.11 \pm 0.64$ & $2.67 \pm 0.24$ \\
\hline E12 & $25 \pm 2$ & $27 \pm 1$ & $40 \pm 3$ & $20 \pm 1$ & $1.08 \pm 0.13$ & $1.60 \pm 0.43$ & $0.80 \pm 0.07$ \\
\hline E13 & $18 \pm 1$ & $22 \pm 1$ & $6 \pm 1$ & $9 \pm 1$ & $1.22 \pm 0.12$ & $0.33 \pm 0.13$ & $0.50 \pm 0.03$ \\
\hline E14 & $5 \pm 1$ & $6 \pm 1$ & $5 \pm 1$ & $10 \pm 1$ & $1.20 \pm 0.30$ & $1.00 \pm 0.52$ & $2.00 \pm 0.43$ \\
\hline E15 & $5 \pm 1$ & $5 \pm 1$ & $3 \pm 1$ & $8 \pm 1$ & $1.00 \pm 0.32$ & $0.60 \pm 0.42$ & $1.60 \pm 0.39$ \\
\hline E16 & $7 \pm 1$ & $9 \pm 1$ & $6 \pm 1$ & $9 \pm 1$ & $1.29 \pm 0.22$ & $0.86 \pm 0.36$ & $1.29 \pm 0.19$ \\
\hline E17 & $13 \pm 1$ & $15 \pm 1$ & $9 \pm 1$ & $41 \pm 2$ & $1.15 \pm 0.10$ & $0.69 \pm 0.18$ & $3.15 \pm 0.19$ \\
\hline E18 & $17 \pm 1$ & $20 \pm 1$ & $15 \pm 2$ & $39 \pm 1$ & $1.18 \pm 0.12$ & $0.88 \pm 0.29$ & $2.29 \pm 0.16$ \\
\hline E19 & $32 \pm 3$ & $33 \pm 3$ & $30 \pm 3$ & $86 \pm 6$ & $1.03 \pm 0.14$ & $0.94 \pm 0.32$ & $2.69 \pm 0.25$ \\
\hline E20 & $8 \pm 1$ & $10 \pm 1$ & $14 \pm 1$ & $11 \pm 1$ & $1.25 \pm 0.17$ & $1.75 \pm 0.54$ & $1.38 \pm 0.18$ \\
\hline E21 & $11 \pm 1$ & $15 \pm 1$ & $14 \pm 1$ & $35 \pm 1$ & $1.36 \pm 0.11$ & $1.27 \pm 0.34$ & $3.18 \pm 0.16$ \\
\hline E22 & $40 \pm 1$ & $47 \pm 15$ & $42 \pm 7$ & $84 \pm 6$ & $1.18 \pm 0.18$ & $1.05 \pm 0.46$ & $2.10 \pm 0.22$ \\
\hline E23 & $91 \pm 14$ & $90 \pm 14$ & $98 \pm 19$ & $193 \pm 10$ & $0.99 \pm 0.22$ & $1.08 \pm 0.50$ & $2.12 \pm 0.33$ \\
\hline E24 & $29 \pm 3$ & $39 \pm 4$ & $22 \pm 1$ & $115 \pm 6$ & $1.34 \pm 0.19$ & $0.76 \pm 0.16$ & $3.97 \pm 0.27$ \\
\hline E25 & $34 \pm 3$ & $47 \pm 5$ & $24 \pm 1$ & $92 \pm 5$ & $1.38 \pm 0.21$ & $0.71 \pm 0.14$ & $2.71 \pm 0.27$ \\
\hline
\end{tabular}



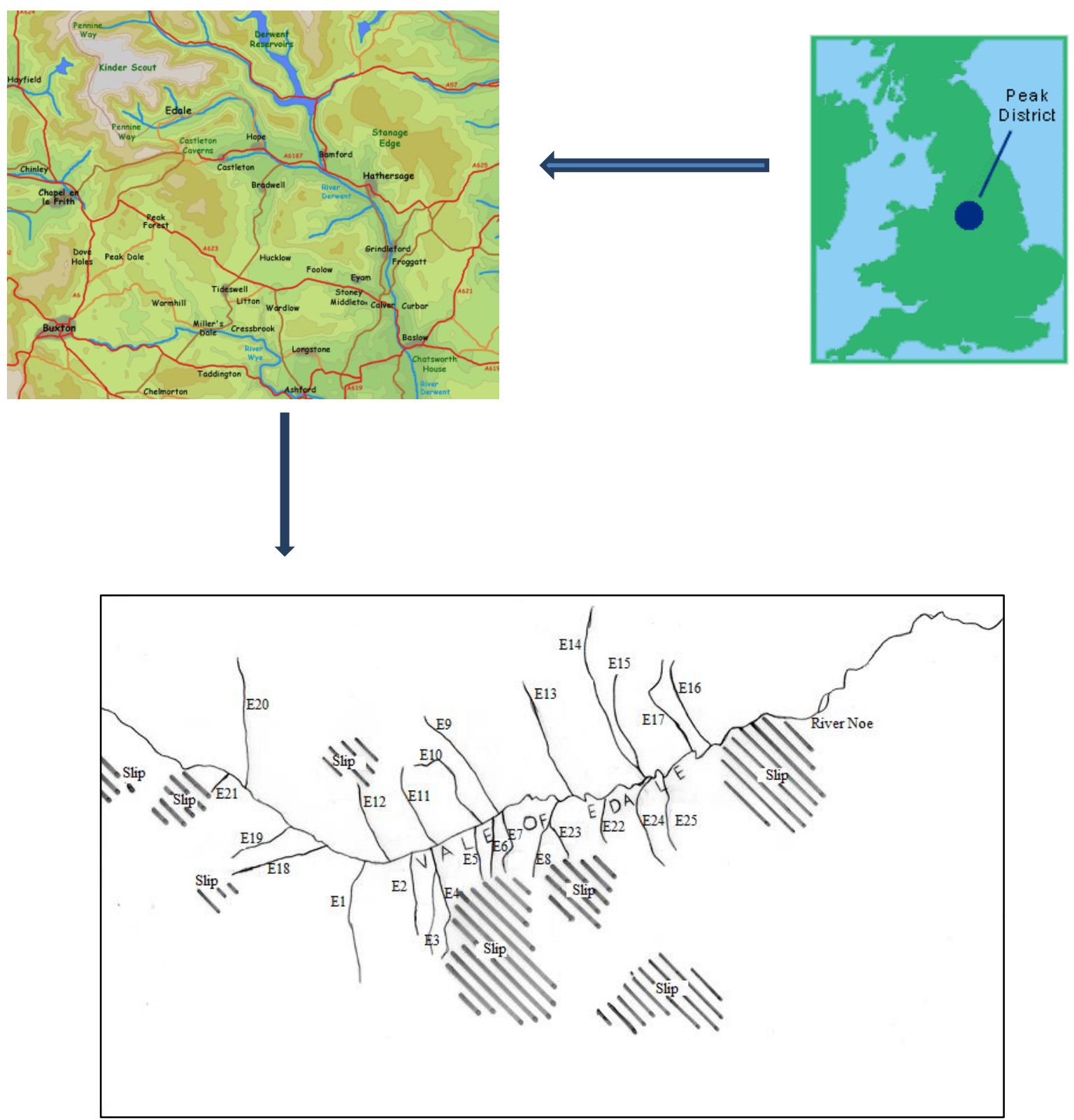

Figure 1 Edale Valley, Derbyshire and the sampling points 


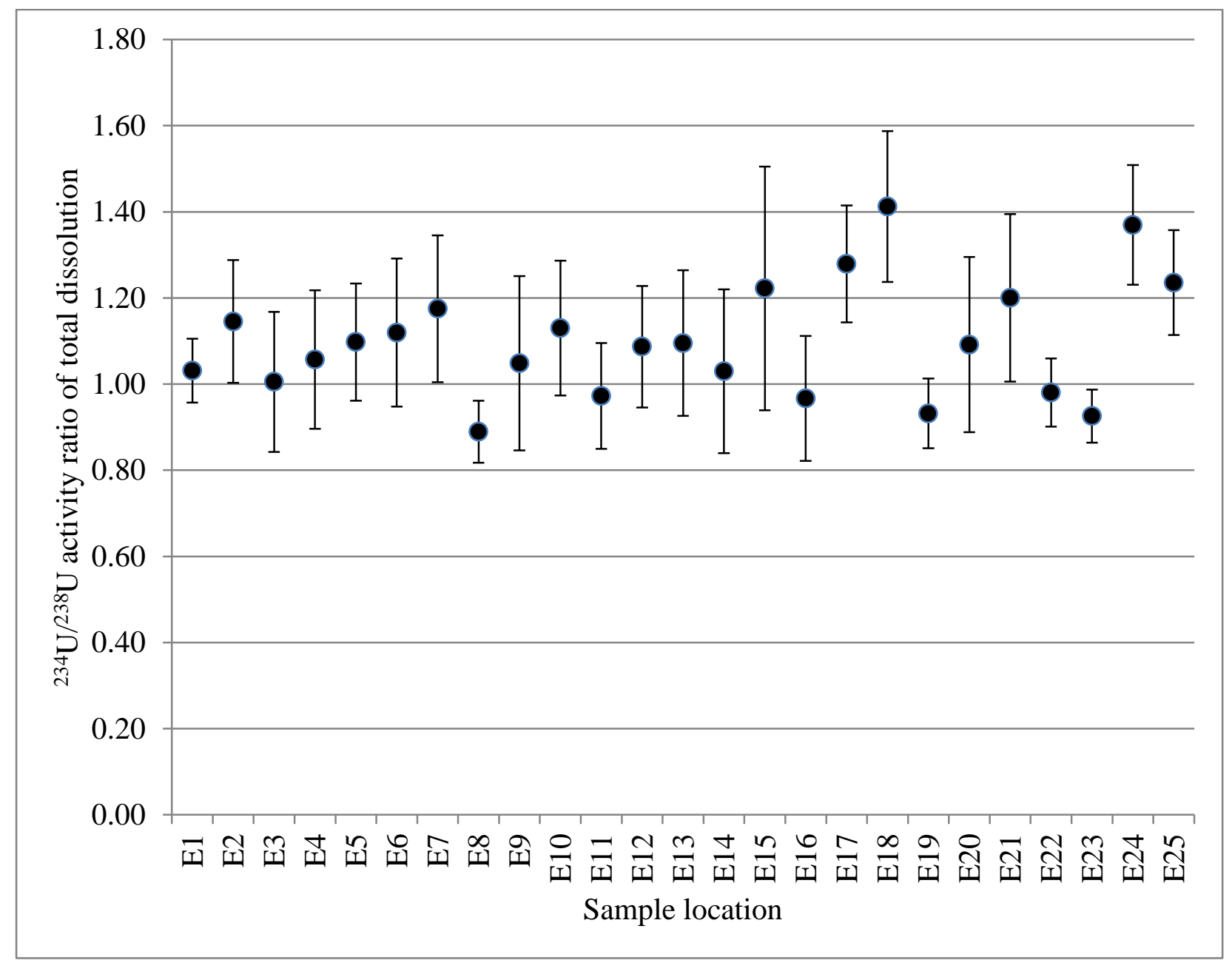

Figure $2{ }^{234} \mathrm{U} /{ }^{238} \mathrm{U}$ activity ratios from total dissolution analyses of sediments from Edale Valley 


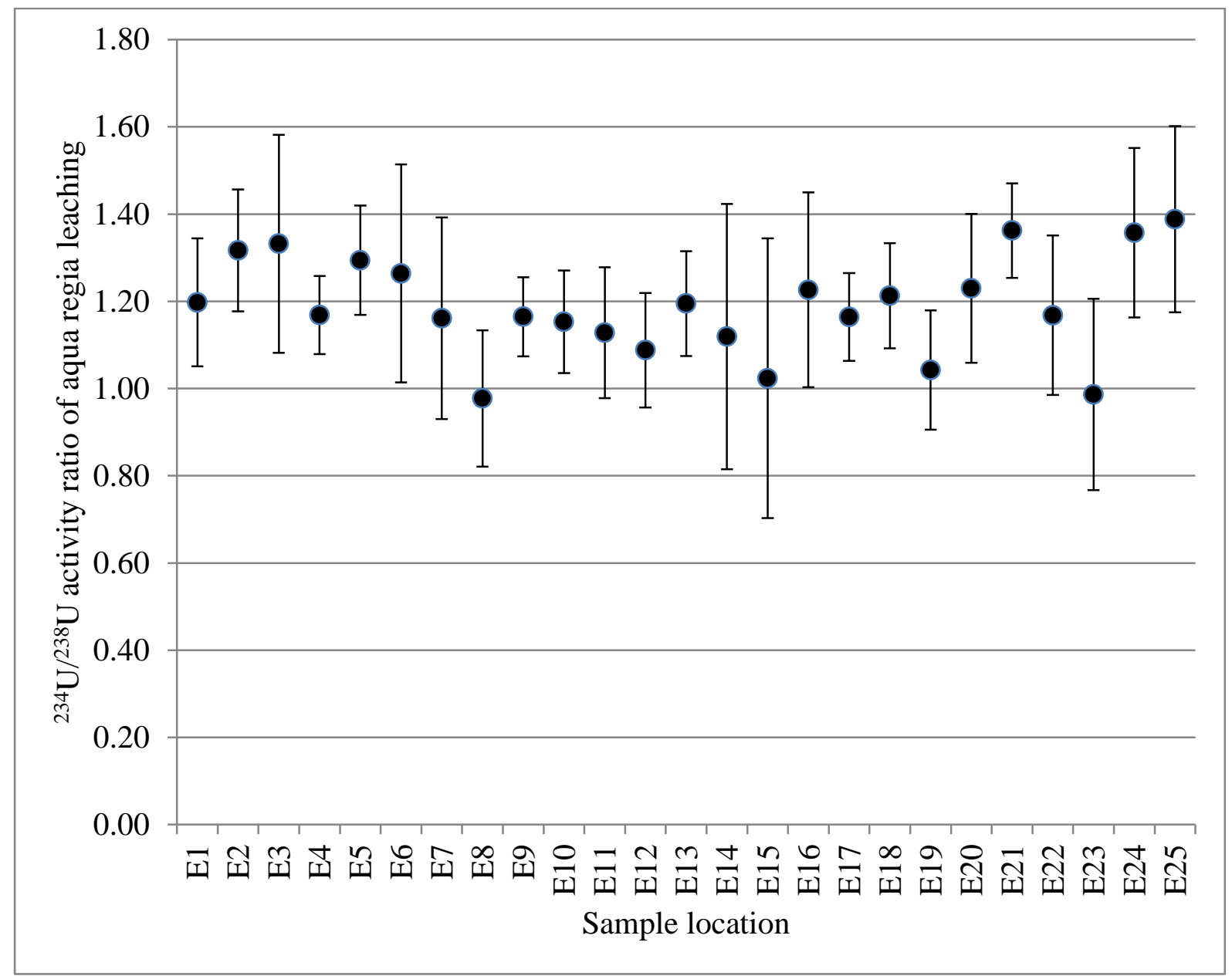

Figure $3{ }^{234} \mathrm{U} /{ }^{238} \mathrm{U}$ activity ratios from the aqua regia leaching analyses of sediments from Edale Valley 


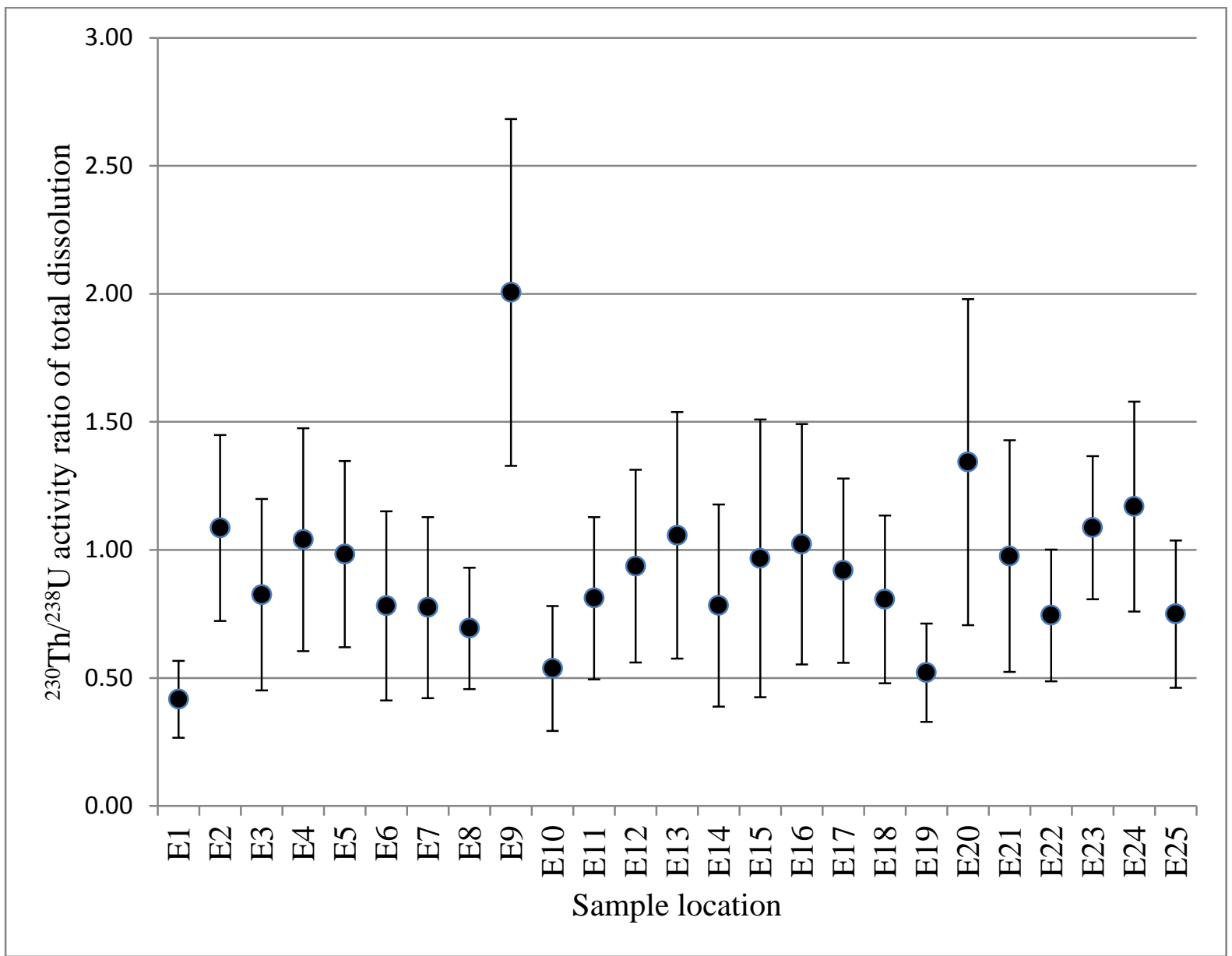

Figure $4{ }^{230} \mathrm{Th} /{ }^{238} \mathrm{U}$ activity ratios from total dissolution analyses of sediments from Edale Valley 


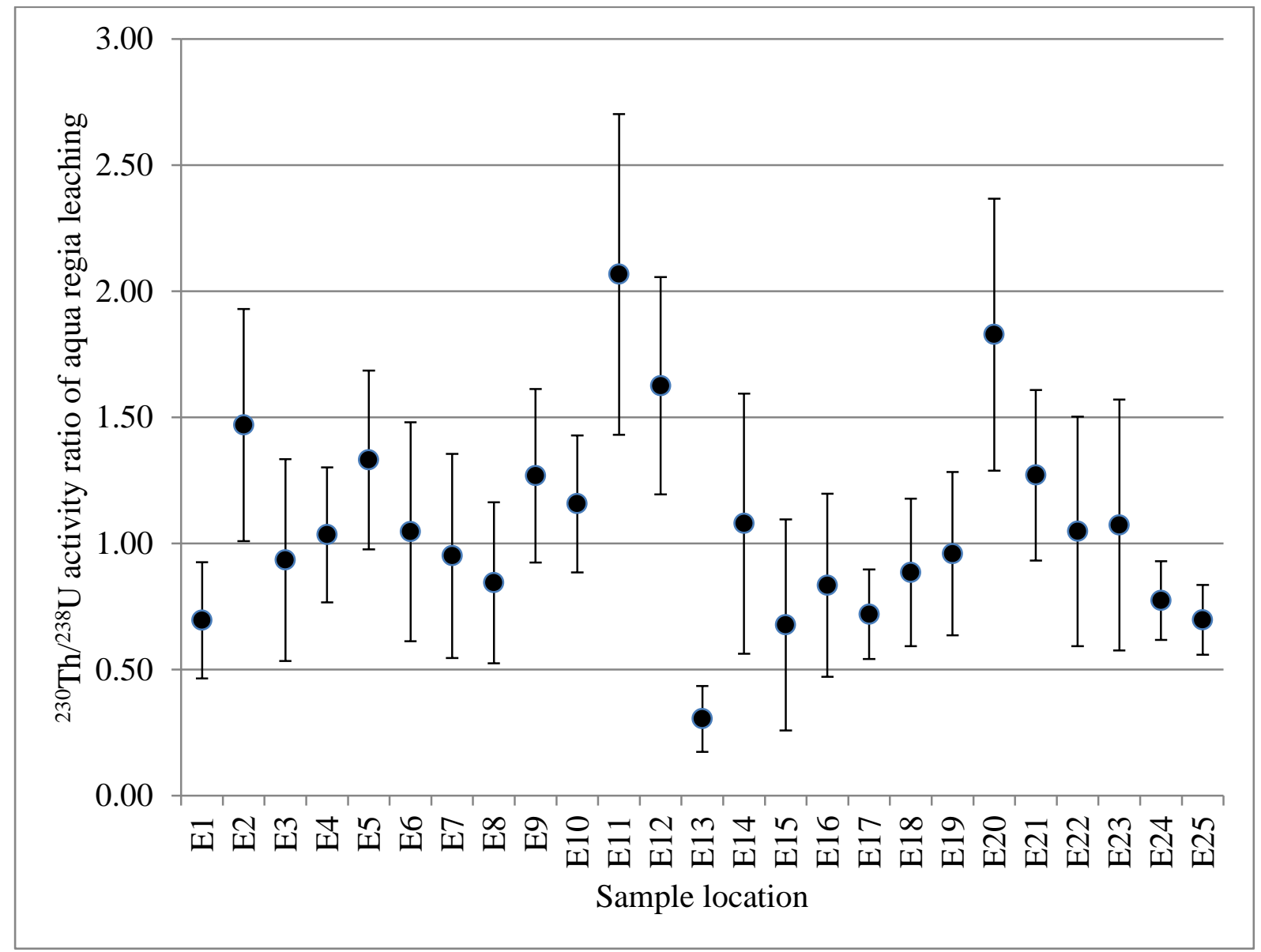

Figure ${ }^{230} \mathrm{Th} /{ }^{238} \mathrm{U}$ activity ratios from aqua regia leaching of sediments from Edale Valley 